\title{
Research on the Construction of "Four in One" Mode of Ideological and Political Education for College Students under the New Media Environment
}

Zhendong Liu, Chunjiang Li

Hebei Normal University for Nationalities Chengde City, Hebei Province, 067000

the construction and practice of "four in one" mode of Ideological and political education in the times Project No. GXDJ202020286

\begin{abstract}
In the new media environment, the education circle pays more and more attention to the quality and effect of college students' ideological and political education. As a compulsory course for universities, university ideological and political education is an important means to implement our country's moral education concept, and it is also an important way to improve the ideological and moral quality of college students. The four-in-one education model can effectively improve the quality of college students' ideological and political education and make them play a better role in educating people. This article discusses the construction strategy of the integrated mode of ideological and political education for college students.
\end{abstract}

Keywords: College Students; Ideological and Political Education; Four in One

The so-called four-in-one is to use the government, school, family and society as the main body of education in teaching, so as to form a joint education model to achieve a more ideal education effect. For college students' ideological and political education, the four-in-one education model can make it have the characteristics of openness, improve the pattern of ideological and political education, and be more conducive to the cultivation of college students. In the new media environment, the ideological quality of college students is more susceptible to the influence of the network environment and the social environment. Therefore, it is necessary to use the integrated thinking teaching model to explore more efficient ideological and political education measures to better complete the teaching goals of ideological and political education, Make the ideological quality of college students develop in a positive direction.

\section{Give full play to the role of universities in ideological and political education}

\subsection{Make full use of classroom teaching and innovate teaching methods}

Classroom is the main position for ideological and political education, and it is also the main way for students to understand the country's political situation and receive ideological education. Colleges and universities should make full use of the teaching value of the classroom to pass on to students the political concepts of Mao Zedong Thought and Marxist theory that fit our country's national conditions, and positively guide students' ideological and moral qualities. At the same time, the ideological and political courses should integrate the development of the times, integrate the policy changes of the party and the country, and improve the comprehensiveness of the ideological and political courses, so that students can understand facts and judge the world situation objectively. However, this kind of teaching content often has the problem of boring, written, slogan, students may find it boring, difficult to generate interest, or feel that they are far away from their own lives, and lack of attention to ideological and political teaching courses. At this time, if the teacher blindly adopts instillation teaching, students can only passively accept the teaching when they cannot Copyright (C) 2020 Zhendong Liu et al.

doi: 10.18282/le.v9i7.1490

This is an open-access article distributed under the terms of the Creative Commons Attribution Non-Commercial License

(http://creativecommons.org/licenses/by-nc/4.0/), which permits unrestricted non-commercial use, distribution, and reproduction in any medium, provided the original work is properly cited. 
obtain a pleasant teaching experience, and cannot actively participate in the teaching. Therefore, teachers should adopt more diversified teaching methods when conducting ideological and political education, inject new content that can arouse students' resonance or attract students' interest, and innovate teaching methods to improve the education effect of the classroom. For example, when teaching an introduction to Mao Zedong Thought, you can use the red gene content advocated by the state to guide students to actively express their understanding of the revolutionary spirit in the form of cooperative discussions and topic debates, and stimulate students' enthusiasm for learning.

\subsection{Carry out campus culture and strengthen cultural construction}

Campus culture is the medium that can most influence the thoughts of college students in daily life. Therefore, colleges and universities should strengthen the construction of campus culture, create a good campus atmosphere for ideological and political education, and give play to the promotion of ideological and political education by campus culture. First of all, colleges and universities should display examples of outstanding students or famous quotes in windows, banners and other areas, and play the role of ideological and political education through the accumulation of influence. Secondly, colleges and universities can organize students to participate in voluntary service activities, museum visits and other activities to positively advocate students' outlook on life and values.

\section{Create a good social atmosphere for ideological and political education}

\subsection{Strengthen the emphasis on social practice activities}

The school's ideological and political education tends to be more theoretical. Students have a correct understanding of ideological and political theory at the knowledge level, but they often fail to translate it into practical applications. At this time, it is necessary to bring students into the real social environment through social practice activities, and deepen students' understanding of the content of ideological and political education through real feelings.

In order to strengthen social practical education activities, in addition to increasing efforts in publicity, the school also organizes corresponding practical tasks in the winter and summer vacations every year to encourage students to actively participate and plan together, so that students can truly experience the joy of practice and mobilize students Passion for practice. In addition, the school also needs to make full use of social resources and resources in the school, choose an appropriate social practice site, and ensure that activities can be carried out smoothly.

\subsection{Develop red resources and update teaching resources}

Since our country has a very long history, it contains a lot of red resources. In the process of ideological and political education for students, the use of red resources is very important. During the period of ideological and political education in colleges and universities, the local red resources must be deeply rooted. Explore, combine resources to stimulate students' enthusiasm, form a resource library through the classification of red resources, which can play an important value in school ideological and political theory courses and campus cultural propaganda. In addition, in order to make students feel the Chinese revolution and national development. Vigorous and vigorous, students can also be organized to visit, truly walk into the red resource site, feel the charm of revolutionary spirit, and enhance students' patriotism.

\section{Strengthen the construction of online ideological and political education}

\subsection{Establish a special website on campus ideological and political education}

At present, more and more colleges and universities have begun to establish their own campus networks, and at the same time use campus networks to transmit information. With the help of campus networks, colleges and universities can establish ideological and political education special websites to expand students' learning paths in the form of pictures and texts. In order to better attract the attention of students, the web design process needs to ensure that the form is novel, the proportions are appropriate, and the students have a good browsing experience. The selection of web content should be as close as possible to the actual life of the students and draw materials from around. Give full play to the role of current affairs and political hotspots, basic policies, etc., so that students can better choose the information they need. In addition, full attention should be paid to the leadership and management of the website. In particular, the 
screening of information must be strict The supervision of violent and commercial hype is forbidden to be published on the website. If inappropriate information is found, it must be dealt with immediately to ensure the safety and purity of the website.

\subsection{Use the Internet to provide a platform for teacher-student communication}

In the process of continuous development of network communication, there are more and more application software on the market. In particular, the application of mass media such as Weibo and official account has become a trend that can provide teachers and students with a platform for communication. Better sharing of current affairs and politics, so that the information obtained by students is not only more targeted, but teachers can give full play to their role as guides on the platform and convey correct ideological and political culture to students. More importantly, this is completely different from the past instillation learning mode. Students can acquire knowledge under relaxed conditions. Not only is the learning method novel, but also conducive to the development of targeted learning guidance.

\section{Concluding remarks}

The "four-in-one" ideological and political education model for college students is based on the current new situation facing higher education, combined with the ideological characteristics of current college students, and summarizes the experience of the past ideological and political education model, and truly integrates the school, family, government and The society is regarded as the main body of education, and the role of these main bodies in ideological and political education is played to provide sufficient guarantee for the future development of students.

\section{References}

1. Dong You. Innovative research on constructing the "four-in-one" training model of ideological and political education for college students[J]. Think Tank Times, 2020(08): 115-116.

2. Zhu Mengfei. My Opinions on Constructing a "Four in One" Model of Entrepreneurship Education for College Students[J]. Youth and Society, 2019(26): 76-78.

3. Zhu Mengfei. My Opinions on Constructing the "Four in One" Model of Entrepreneurship Education for College Students[J]. China Adult Education, 2019(09): 44-46. 